\title{
Syntactic Complexity on Extroverted and Introverted Indonesian Language Learners' Written Products
}

\author{
Siti Aisah Ginting*
}

Faculty of Languages and Arts, Universitas Negeri Medan, Indonesia

Corresponding author: Siti Aisah Ginting, E-mail: aisyah_ginting@yahoo.co.id

\begin{tabular}{l} 
ARTICLE INFO \\
\hline Article history \\
Received: September 04, 2018 \\
Accepted: October 29, 2018 \\
Published: October 31, 2018 \\
Volume: 6 Issue: 4 \\
\hline
\end{tabular}

Conflicts of interest: None Funding: None

\begin{abstract}
The objective of this study was to examine the significance of difference between introverted and extroverted learners in terms of syntactic complexity (Simple Sentences [SS], Compound Sentences [CpdS], Complex Sentences [CpxS], and Compound Complex Sentences [CCS]). The data were collected from written products of 30 introverted and 30 extroverted language learners in the Faculty of Languages and Arts, Universitas Negeri Medan, Indonesia. SPPS (Version 21) was used to analyze the data. It was found that there was a significant difference between introverted and extroverted learners' written product in terms of syntactic complexity. The introverted learners wrote more SS than extroverts did. In contrast, extroverts wrote more CpdS and CCS than introverts did in their written products. On the other hand, there was no significant difference between the groups in $\mathrm{CpxS}$. To sum up, language learners wrote different kinds of sentences in their written products.
\end{abstract}

Key words: Syntactic Complexity, Personality, Introversion, Extroversion, Writing, Language Learner

\section{INTRODUCTION}

Language is a tool of communication. Prasad (2012: 2) concludes, "Language is an organization of sounds produced from the mouth to convey some meaningful message. It is also device of expression of thoughts or ideas in written or graphic form". Therefore, the main purpose of language is to convey the message to the audience or participant.

Study about language, there are basically four (4) kinds of activities involved. They are listening, speaking, reading and writing. On the other hand, language educators tend to talk about the way we use the language in terms of four skills, which are reading, writing, speaking and listening skills. These are often divided into two kinds. "Receptive skills" is a term used for reading and listening, skills where the meaning is extracted from the discourse. "Productive skills" is a term for speaking and writing, skills where learners actually have to produce language themselves (Harmer, 2007).

Practically, writing skill is normally taught after the three other skills because writing skill is the most complicated skill which most of language learners do not like this skill or do not interest in this skill. It is linear with what Sanjaya, Azman and Sumarsih (2015) claimed that writing is the most difficult skill for student in learning language because writing requires review and revise for not only once but maybe many times. That is why writing skill is more considered as a non-stop process occurring than a product in a continuum of learning and revisions (Steele, 2004).
Moreover, Sanjaya (2015), in his thesis, he stated that there are many aspects that effect the students' writing competences and performances. They are intelligence, aptitude, learning style and strategies, personality, anxiety, motivation and age. It is in line with the other researchers such as Skehan (1989) and Wakamoto (2000). Therefore, there is a strong correlation between writing and personality. In addition, Erton (2010) claimed that students' personalities are the main factors of differences in their writing results. Hence, the impact of personality on writing competence and performance is unavoidable.

Literally, there are many variables in personality aspect e.g. biology, traits, intelligent and so on. However, among the number of personalities, personality traits (extroversion and introversion) has been the most studied in language competence and performance because extrovert and introvert personalities are more to the behavior and action of the learners' expression in using the language (Dornyei, 2005).

Furthermore, Oshima and Hogue (1999) theoretically stated that morphology, syntax, phonetic and semantic are the linguistic elements in written text. In addition, Brown (2007) required the syntax element as one of the indicator in assessing the students' writing. Then, syntax is a term used for a study of sentence constructions (Finch, 2000). It means that syntax is one of the main linguistic elements required in composing a written text. Without a proper syntax, the written text is not understandable and the message in the written 
text will not be delivered properly and comprehensively to the reader.

Based on the statements above, it can be logically seen that there is a correlation between personality and syntax in writing text. Therefore, it is very important to study the impact of personality (extroversion/introversion) on syntactic complexity of students' writing. The objective of this study is to examine the difference between extroverted and introverted learners in composing a text. So, teachers or lecturers will know the types of students' written text and can give some ways or suggestion to students in order to improve students' achievements in writing skill.

\section{LITERATURE REVIEW}

\section{Personality}

Every person is different one another because each individual has his/her own uniqueness. In accordance with, Boyle, Mathews and Saklofske (2008) stated that personality can be defined in to two ways which are 1) characterization and individuality, or as 2) the subjacent structure that brought on the position of characteristics. For this definition, each individual naturally brings different character, attitude, behavior and actions. In addition, personality theory claimed that each person is different and uniquely characterized.

Personality has been studied in various manners pertaining to different forms of processing and learning styles (Sharp, 2008). Language of personality has been divided by psychologists (Klages, 1926; Baumgarten, 1933; Allport \& Odbert, 1936) as essential and beneficial for every day interaction. Hence, personality is an elemental factor in effectuating educational aims for learners in studying any languages (Erton, 2010).

The effects of personality for learners' proficiency from scholastic accomplishment in language learning have been examined by scholars (Bratko, Chamorro-Premuzic, \& Saks, 2006). The most studied personalities in language learning accomplishment are extroversion and introversion. Myers et el. (1998) define extroversion preferences as "Directing energy mainly toward the outer world of people and objects" and introversion preferences as "Directing energy mainly toward the inner world of experience and ideas" (p. 6). Based on personality type classification developed by Eysenck and Eysenck (1975), extraverted and introverted people engaged in emotional face processing were found to show differential cortical activations (Fink, 2005).

Furthermore, Brown (2000) stated that extroversion is a dimension to which a person has a fundamental need to be presented for self-image improvement, self-esteem, and sense of completeness from other person. In contrast, introversion is an extent to which a person derives a sense of wholeness and fulfillment apart from reflection from other person. Additionally, Eysenck and Eysenck (1975) claimed that extroverts like to speak and normally they are unworried, broadminded and confident, meanwhile, extroverts like to read and write, and they normally avoid to do mistakes and communicate for important talk only.

In accordance with explanation above, looking at the very contrast personality of extroverted and introverted learners, there must be possible differences in the way they construct sentences in writing. Therefore, investigating the syntactic complexity of extroverts and introverts in their written text seems to be essential for the benefit of language educational goals.

\section{Syntactic Complexity}

Syntax is linguistic element in a language. Prasad (2012) defines syntax as "the way that words and phrases are put together to form sentences in a language". In addition, literally, the word 'syntax' consists of two word-elements, syn-, the latinized form of Greek preposition 'sun' which means together and -tax, derived from a Greek root, which means to put in order. The meaning of syntax is, thus, putting things together in an orderly manner. In brief, it is the grammar of sentences, a study of the ways in which words can be strung together to form acceptable sentences (Prasad, 2012).

Syntactic complexity is one of the three important elements in writing development in addition to fluency and accuracy (Hunt, 197s0). Even though many studies have examined syntactic complexity in the past, measures used to examine the syntactic complexity have been still a challenge for researchers because literally, syntactic complexity is a broad study. There are many elements included in syntactic complexity such as word, phrase, clauses, sentence types, and T-unit. Although syntactic complexity is a wide study, it is normally categorized in to six (6) clusters. They are T-units, sentences, clauses, phrases, words, and combined measures (Jagaiah, 2016).

Since the syntactic complexity is a large topic to be studied, the category of the syntactic complexity in this recent study is narrowed down to sentence types in a written product.

Different language may have different sentence types but in Indonesian language there are four types of sentences according to grammatical structure of the sentences: 1) kalimat tunggal (simple sentence), 2) kalimat majemuk (compound sentence), 3) kalimat majemuk bertingkat (complex sentence) and 4) kalimat majemuk campuran (compound-complex sentence). Elaboration for each type is as below:

Simple Sentence contains only one subject and one predicate. Even though the sentence is very long but if it has only one subject and one predicate, it is still categorized as simple sentence. For instance: "mahasiswa semester tiga sedang berdiskusi di ruang kelas" (the third semester students is discussing in classroom).

\begin{tabular}{lll}
\hline $\begin{array}{l}\text { mahasiswa semester } \\
\text { tiga }\end{array}$ & $\begin{array}{l}\text { (the third semester } \\
\text { students) }\end{array}$ & $=$ Subject \\
sedang berdiskusi & (is discussing) & $=$ Predicate \\
di ruang kelas & (in classroom) & $=$ Complement \\
\hline
\end{tabular}

Compound Sentence contains two or more independent simple sentences. Normally, the sentences are combined by conjunction such as and, or, therefore, but, hence, thus, so that and etcetera. For instance: "Amerika dan Jepang tergolong negara maju tetapi Indonesia dan Brunai Darussalam tergolong negara berkembang" (America and Japan are considered as developed countries but Indonesia and Brunei Darussalam are considered as developing countries). 


\begin{tabular}{|c|c|c|}
\hline Amerika dan Jepang & (America and Japan) & $=$ Subject \\
\hline tergolong & (are considered as) & $=$ Predicate \\
\hline negara maju & (developed countries) & $=$ Object \\
\hline tetapi & (but) & $=$ Conjunction \\
\hline $\begin{array}{l}\text { Indonesia dan Brunai } \\
\text { Darussalam }\end{array}$ & $\begin{array}{l}\text { (Indonesia and } \\
\text { Brunei Darussalam) }\end{array}$ & $=$ Subject \\
\hline tergolong & (are considered as) & $=$ Predicate \\
\hline negara berkembang & $\begin{array}{l}\text { (developing } \\
\text { countries) }\end{array}$ & $=$ Object \\
\hline
\end{tabular}

From this sentence, it can be seen that before and after the conjunction there is independent simple sentence. In addition, the position of the conjunction normally should be in between.

\section{Complex Sentence}

Complex Sentence contains one independent clause and one or more dependent clauses. The main idea or sentence is put as main clause and the subordinate is put as subordinate clause. Normally, the subordinate clause is from the view of time, cause, effect, purpose, requirements, and etcetera such as although, even though, because, if, so that, while, when, after, before, and etcetera. For instance: "Walaupun hari ini hujan, Andy tetap pergi ke sekolah" (although today is raining, Andi is still going to school).

\begin{tabular}{lll}
\hline $\begin{array}{l}\text { Walaupun hari ini } \\
\text { hujan }\end{array}$ & $\begin{array}{l}\text { (although today is } \\
\text { raining) }\end{array}$ & $\begin{array}{l}\text { Dependent } \\
\text { clauses }\end{array}$ \\
$\begin{array}{lll}\text { Andy tetap pergi } \\
\text { ke sekolah }\end{array}$ & $\begin{array}{l}\text { (Andi is still going } \\
\text { to school) }\end{array}$ & Independent \\
clause
\end{tabular}

Compound-Complex Sentence contains two independent clauses and one or more dependent clauses. For instance: "kami pulang tetapi mereka masih bekerja karena tugasnya belum selesai" (we have gone home but they have been still working because their task has not been finished yet).

\begin{tabular}{ll}
\hline kami pulang & \\
(we have gone home) & $=$ Independent clause \\
tetapi & $=$ Conjunction \\
(but) & \\
mereka masih bekerja & $=$ Independent clause \\
(they have been still working) & \\
karena tugasnya belum selesai & $=$ Dependent clause \\
(their task has not been finished yet) &
\end{tabular}

According to the explanation above, the four types of sentences base on the grammatical structure in Indonesian Language are similar with sentence type in English language. Therefore, in students' language written product must contain these types of sentences. Related to the students' personality traits, each student may have different way of composing a text. On that reason, syntactic complexity needs to be investigated in different personality students' written product.

\section{Relationship between Syntactic Complexity and Personality (Extroversion and Introversion)}

As Eysenck and Eysenck (1975) claimed that extroversions like to speak and normally they are unworried, broadminded and confident, meanwhile, extroversions like to read and write, and they normally avoid to do mistakes and communicate for important talk only. Then, Syntax is the grammar of sentences, a study of the ways in which words can be strung together to form acceptable sentences (Prasad, 2012). Furthermore, syntactic complexity is one of the three important elements in writing development in addition to fluency and accuracy (Hunt, 1970). Therefore, since extroverted students tend to be confident and unworried, they might write so many sentences and based on their attitude they might a lot in complex sentences. If they write more complex sentences in their writing, some teachers will think they are very good in writing even though we still need to see the correctness of their sentences. On the other hand, the introverted students tend to communicate only the important thing and they tend to avoid mistake. Base on this claim, introverted students might only write simple sentences in their essay. Therefore, to examine the different between extroverted and introverted students in writing and essay in terms of the complexity of the sentences, a study has been conducted.

\section{Previous Study on Personality and Syntactic Complexity}

Practically, there are many ways of examining the syntactic analysis. Different ways will present different results and findings in the research. Recently, Sanjaya (2015) concluded in his thesis that extroversion students made more syntactic errors in their descriptive writing than introversion students did. The number of the errors was twice. Base on this findings, it can be seen that introversion is more aware and careful in composing a text than the extroversion.

Moreover, Zainuddin (2016) claimed that introverted students outperformed extroverted students in the test of syntax ability in descriptive essay. Furthermore, he said that the introverted group's sentence construction had fewer errors and was easier to understand. In contrast, the extroverted group tended to make more errors and it was more difficult to understand their writing because the clauses were sometimes too long and complex to understand.

On the other hand, Vaezi (2012) confirmed that extroversion and introversion did not contribute to any significant differences in syntactic complexity which was defined as sentence length and ratio of subordinates. It means that in terms of the style of syntax there is not much difference between the written products but in terms of the types of sentences in the written product there is need for further investigation. Therefore, there must be a possible difference between extroversion and introversion in syntactic complexity (type of sentences) in written product.

\section{METHODS}

\section{Participants}

This research was administered to 30 extroverted and 30 introverted Indonesian language learners in the Faculty of Languages and Arts, Universitas Negeri Medan, Indonesia. The participants were aged between 19 and 21. The participants that were purposively selected were 72 extroverts 
and 44 introverts based on their scores on the Myers Briggs Types Indicator (MBTI) questionnaire.

\section{Instruments}

Myers Briggs Types Indicator (MBTI) questionnaire: Myers \& Briggs (1998) developed this questionnaire. There are 70 questions in this questionnaire. The questions, which examine the respondent's extroversion or introversion (E/I) personality, are question number $1,8,15,22,29,36,43,50$, 57 and 64 only. Even though the items for E/I are only ten (10) questions, they should not be taken out from complete questionnaire since this questionnaire was integrated and the rest of the questions actually only to measure what types of E/I the participants are. In addition, quite numerous scholars such as Wakamoto, (2007), Marefat (2006), Carrell (1995) used this questionnaire to classify the personality types of participants in their research on correlation of personality traits with language skills.

\section{Writing task}

A writing task was administered to extroverted and introverted groups. The task was asking the participants to write an argumentative essay in Indonesian Language about 220 to 250 words. The topic of the task was about a social media. The question is as following:

Sekarang ini banyak masalah yang diakibatkan oleh penggunaan sosial media terutama "Facebook" yang sangat bebas di Indonesia seperti, penipuan, penyebaran berita bohong, pembulian dengan kata-kata dan sebagainya. Oleh karena itu, pemerintah Indonesia ingin melarang dan menutup "Facebook" di Indonesia. Sejauh mana kamu setuju dan tidak setuju kepada sikap pemerintah tersebut, tulisakn pendapatmu dalam sebuah esai sepanjang 220 ke 250 kata-kata.

Nowadays, there are so many problems which are caused by uncontrolled use of social media, Facebook, in Indonesia like, cheating, publishing hoax, bullying, and so on. Therefore, Indonesian government announced that Facebook should be banned. To what extent do you agree or disagree with it. Write an argumentative essay in about 220 to 250 words.

The task consisted of only one argumentative topic. The argumentative genre was selected since argumentative essay is one of the genres in writing skill that have to be mastered by the Indonesian language learners in Indonesia.

\section{Data Analysis}

The sentence types in each essay were grouped and counted manually. Then, the number of each type of sentences on extroverted and introverted groups' essays was listed and tabulated by using independent samples $t$-test in Statistical Package for Social Science (SPSS) version 2.1 to find out the statistical significance of difference between extroverted and introverted groups in constructing the sentences in written product.

\section{RESULT AND DISCUSSION}

From 30 introverted and 30 extroverted language learners' written products, the number of each type of sentences were collected and tabulated by using independent samples $t$-test to compare the syntactic complexity between introverted and extroverted learners. Hence, the comparison is shown as follow:

Table 1 shows the values of means, standard deviation and standard error of the mean for the two groups in four (4) types of sentences according syntactic complexity. The mean score of the introverted learners in Simple Sentences (SS) was 11.47 higher than the extroverted learners. In contrast, in Compound Sentences (CpdS) the extroverted learners outperformed the introverted learners about 4.30 points. Meanwhile, in terms of Complex Sentences (CpxS), there is not much difference between introverted and extroverted groups; the extroverted learners were only 1.73 points higher than the introverted group. But, in Compound Complex Sentences the extroverted group was 4.33 points higher than introverts. Overall, there were differences between extroverted and introverted groups in terms of syntactic complexity of their written products. To examine the significance of difference between introverted and extroverted groups in syntactic complexity, the data were tabulated and computed by using independent samples $t$-test. The result of the test is presented in the Table 2.

An independent samples $t$-test was computed using SPSS (Version 21) to find out the difference between extroverts and introverts in terms of syntactic complexity. The difference was found to be statistically significant for SS $t(58)=46.255$, $p \leq .05$, for CpdS $t(58)=-17.883, p \leq .05$, and for CCS $t$ (58) $=-22.501, p \leq .05$. The results indicated that there was significant difference between extroverted and introverted group in terms of sentence types, which are in Simple Sentences, Compound Sentences and Compound Complex Sentences. But for CpxS $t(58)=.724, p \geq .05$, the result indicated that there was no significant difference between extroverted and introverted groups which means they have similar number of this type of sentences in their written products.

The current results agree with Sanjaya et al.'s (2015) who reported a significant difference between extroverts and introverts in their writing skill. In addition, Jagaiah (2016) concluded that syntactic complexity has a strong relationship with writing quality; the more complex of the sentences

Table 1. The comparison of introverted and extroverted learners' syntactic complexity

\begin{tabular}{llcccc}
\hline & Personality & $\mathbf{n}$ & $\mathbf{M}$ & SD & Standard error mean \\
\hline SS & Introverted & 30 & 16.47 & 1.14 & 0.21 \\
& Extroverted & 30 & 5.00 & 0.74 & 0.14 \\
\multirow{2}{*}{ ppdS } & Introverted & 30 & 4.00 & 0.69 & 0.13 \\
& Extroverted & 30 & 8.30 & 1.12 & 0.20 \\
\multirow{2}{*}{ CpxS } & Introverted & 30 & 8.00 & 1.39 & 0.25 \\
& Extroverted & 30 & 7.73 & 1.46 & 0.27 \\
CCS & Introverted & 30 & 0.87 & 0.51 & 0.09 \\
& Extroverted & 30 & 5.20 & 0.92 & 0.17 \\
\hline
\end{tabular}




\begin{tabular}{|c|c|c|c|c|c|}
\hline & \multicolumn{2}{|c|}{ Levene's test for equality of variances } & \multicolumn{3}{|c|}{$t$-test for equality of means } \\
\hline & $\mathbf{F}$ & Sig. & $\mathbf{t}$ & df & p \\
\hline \multicolumn{6}{|l|}{ SS } \\
\hline Equal variances assumed & 12.688 & 0.001 & 46.255 & 58 & 0.000 \\
\hline Equal variances not assumed & & & 46.255 & 49.948 & 0.000 \\
\hline \multicolumn{6}{|l|}{ CpdS } \\
\hline Equal variances assumed & 8.816 & 0.004 & -17.883 & 58 & 0.000 \\
\hline Equal variances not assumed & & & -17.883 & 48.473 & 0.000 \\
\hline \multicolumn{6}{|l|}{ CpxS } \\
\hline Equal variances assumed & 1.275 & 0.264 & 0.724 & 58 & 0.472 \\
\hline Equal variances not assumed & & & 0.724 & 57.857 & 0.472 \\
\hline \multicolumn{6}{|l|}{$\mathrm{CCS}$} \\
\hline Equal variances assumed & 32.767 & 0.000 & -22.501 & 58 & 0.000 \\
\hline Equal variances not assumed & & & -22.501 & 45.011 & 0.000 \\
\hline \multicolumn{6}{|l|}{$\mathrm{CCS}$} \\
\hline Introverted & 30 & .87 & .51 & .09 & \\
\hline Extroverted & 30 & 5.20 & .92 & .17 & \\
\hline
\end{tabular}

in written product, the higher the quality of the writing. The finding of this current study indicated that introverted learners wrote more Simple Sentences (SS) and fewer Compound Complex Sentences (CCS). Therefore, teachers should encourage and teach them to write more CCS until they reach a proportionate amount of CCS in their writings. On the other hand, the extroverts wrote more Compound Sentences and Compound Complex Sentences and fewer Simple Sentences in their essays. Therefore, they should be monitored not to write lengthy sentences in order for reader to understand the content. In so doing, teachers have to encourage students to balance syntactic complexity in their writings.

\section{CONCLUSION}

The results of the present study showed that there is a difference between extroverted and introverted language learners in writing an essay particularly in constructing sentences. This might happen because their personalities automatically oblige them to do so. However, even though they have natural differences, both introverts and extroverts are able to improve their writing skills. Teachers should monitor, guide and train these learners on how to write a variety of sentences in their essays.

\section{REFERENCES}

Allport, G. W., \& Odbert, H. S. (1936). Trait-names: A psycho-lexical study. Psychological monographs, 47(1).

Baumgaerten, F. (1933). Die Charaktereigensehaften [The Character Traits]. Bern: Francke.

Boyle, G. J., Matthews, G., \& Saklofske, D. H. (Eds.). (2008). The Sage handbook of personality theory and assessment: Personality measurement and testing (Vol. 2). London: Sage.

Bratko, D., Chamorro-Premuzic, T., \& Saks, Z. (2006). Personality and school performance: Incremental validity of self-and peer-ratings over intelligence. Personality and Individual Differences, 41(1), 131-142.

Brown, H.D. (2000). Principles of language learning and teaching ( $4^{\text {th }}$ edition). New York: Pearson Longman.

Brown, H. D. (2007). Teaching by Principles; An Interactive Approach to Language Pedagogy ( $3^{\text {rd }}$ edition). New York: Pearson Longman.

Carrell, P. L. (1995). The effects of writers' personalities and raters' personalities on the holistic evaluation of writing. Assessing Writing, 2, 153-190.

Dörnyei, Z. (2005). The Psychology of the Language Learner: Individual Differences in Second Language Acquisition. Mahwah: Lawrence Erlbaum Associates.

Erton, I. (2010). Relation between personality traits, language learning styles and success in foreign language achievement. Journal of Education, 38, 115-126.

Eysenck, H. J., \& Eysenck, S. B. G. (1975). Manual for the Eysenck Personality Inventory. Sandiego, California: Educational and Industrial testing service in http://legacy.library.ucsf.edu/tid/pfd3aa00/pdf.

Finch, G. (2000). Linguistic Terms and Concepts. New York: St. Martin's Press.

Fink, A. (2005). Conducting research literature reviews: From the internet to paper. London: Sage.

Harmer, J. (2007). The Practice of English Language Teaching. Fourth Edition. Cambridge: Pearson Longman.

Hunt, K.W. (1970). Syntactic maturity in school children and adults. Monographs of the Society for Research in Child Development, 35(1), 1- 61.

Jagaiah, T. (2016). Syntactic complexity measures: Variation by genre, grade-level, and students writing abilities(Unpublished manuscript)

Klages, L. (1926). Die psychologischen Errungenschaften Nietzsches.

Marefat, F. (2006). Student writing, personality type of the student and the rater: Any interrelationship? Reading 
Matrix: An International Online Journal, 6(2), 116-124.

Myers, I. B., \& Briggs, K. C. (1998). Myers- Briggs Type Indicator. STEP I/Self- Scorable, Form M. Palo Alto, CA: Consulting Psychologists Press.

Oshima, A. \& Hogue. (1999). Writing Academic English ( $3^{\text {rd }}$ ed.). New York: Addison Wesley Publishing Company.

Prasad, T. (2012). A Course in Linguistics (2 ${ }^{\text {nd }}$ ed.). New Delhi: PHI Learning.

Sanjaya, D. (2015). Syntactic Analysis of Extrovert and Introvert EFL Learners' Descriptive Writing. (Unpublished $\mathrm{PhD}$ Thesis) Universiti Utara Malaysia, Malaysia.

Sanjaya, D., Mokhtar, A.A., \& Sumarsih (2015). The Impact of Personality (Extroversion/Introversion) on Indonesian EFL Learners' Essay Writing Achievement. Asian EFL Journal, 87(10), 4 - 19.
Sharp, A. (2008). Personality and second language learning. Asian Social Science, 4(11), 17.

Skehan, P. (1989). Individual Differences in Second Language Learning. London: Edward Arnold.

Steele, V. (2004). Product and process writing: a comparison. Retrieved, from http://www.teachingenglish.org.uk.

Vaezi, S., \& Kafshgar, N. B. (2012). Learner characteristics and syntactic and lexical complexity of written products. International Journal of Linguistics, 4(3), 671-687.

Wakamoto, N. (2000). Language learning strategy and personality variables: Focusing on extroversion and introversion. IRAL. International review of applied linguistics in language teaching, 38(1), 71-81.

Zainuddin, Z. (2016). The Impact of Personality: Extrovert vs. Introvert on the Ability in Syntax in Essay Writing. Studies in English Language and Education, 3(2), 158-169. 